\title{
Biochemical parameter evaluation Buffalos and Cows with brucellosis in Missan Province
}

\author{
Zainab A.J.R. Al-Ali, Ali Y. Abd ,Tbark R. Jamail
}

Department of biology, college of science, University of Missan, Missan , Iraq

\section{Article Info}

Received: January, 2019

Revised:February,2019

Accepted:April,2019

\section{Keywords}

Brucellosis, buffalo, cows, Rose Bengal Plate Test, biochemical test

Corresponding Author

Zainab.alali@yahoo.com

\begin{abstract}
The present study was undertaken to assess and compare the serum biochemical parameters of buffalos and cows brucellosis with negative ones.A total of ninety three blood samples were collected randomly from different age and flocks of non vaccinated local buffalos and cows. Rose Bengal Plate Test was depended for screening the collected blood samples in addition to measure serum biochemical parameters included total protein, albumin, cholesterol, triglyceride, urea, creatinine, aspartate transaminase (AST) and alanine transaminase ( ALT). It was observed that $12(12.9 \%)$ samples positive for Brucella spp. The results of biochemical parameters shown that ALT, AST and total protein were increased significantly $(\mathrm{p}<0.05)$ in buffalo positive for brucellosis than those of negative results .The values of the albumin, cholesterol, triglyceride, urea and creatinine did not show significant variation between the Brucella positive and negative buffalo. The values of serum cholesterol, triglyceride and creatinine concentrations for Brucella positive cows were declined significantly ( $\mathrm{p}<0.05)$ when compared to negative ones. The value of AST was elevated significantly $(\mathrm{p}<0.05)$ in Brucella positive cows. It was noticed that there were no significant differences between positive and negative cows considering total protein, albumin, urea and ALT. cows . These changes in biochemical parameters of the blood indicate that brucellosis causes deteriorative effects on health of buffalo and cows infected with Brucella.
\end{abstract}

\section{Introduction}

Brucellosis is an important bacterial zoonotic infection with a worldwide distribution among humans and animals, caused by different Brucella species (Pappas etal. 2006 ; Maadi etal., 2011). The recognized Brucella species are named according to their host preferences such as B. abortus which infects cattle ( Corbel , 1997).The incidence of Brucellosis varies considerably among breed, areas and country(Ghani etal.,1995).Brucellosis may cause considerable economic losses especially it reduces productivity and lead to abortion (EL-Boshy etal.,2009).Abortion in last trimester, birth of unthrifty newborn, retained placenta in female and orchitis, epididyimitis in male animals are the most manifestations of brucellosis in animals 
(Radostit etal. 2007) and it may lead to temporary or permanent infertility in affected animals (Cutler etal. 2005). Human infection usually occurred by the consumption of raw milk and its products as well as occupational exposure to infected live animals or carcasses during slaughter (Young, 1995).

The study of biochemical parameters in the blood can give valuable information about the animal health. Brucella is a significant animal pathogen with adverse effects on different vital organs such as heart, liver, kidney and muscle which can cause damage, functional disorders which may cause alterations in biochemical parameters (Sker etal. 2001; Bouhroum etal. 2012). Several tests such as Rose Bengal Plate Test (RBPT), Standard Tube Agglutination Test (STAT), Enzyme Linked Immunosorbent Assay (ELIZA), Milk Ring Test ( MRT) and the Fluorescence Polarization Assay are commonly used for the detection of antiBrucella antibody (Altuglu et al., 2002; Kumar et al., 2015). Little informations are available about the biochemical parameters in buffalos and cows with Brucellosis. This study was conducted to evaluate any alterations in different biochemical parameters of the buffalos and cows diagnosed with brucellosis.

\section{Material and Methods}

\section{1- Animals}

The present study was carried out at the department of biology, college of Science, Missan University in Missan proviance, Iraq. In period from $26 / 11 / 2016$ to $22 / 3 / 2017$.A total of ( 93 ) blood samples ( 57 male and 36 female) were collected randomly from different ages about (1-4) year, and flocks of non-vaccinated local buffalos and cows. The collected blood samples were kept and transferred in a polyethylene cool box to the laboratory.

\section{2- Blood samples}

Ten $\mathrm{ml}$ of blood was collected in vacationer EDTA- tube. Plasma was separated from the blood by centrifugation at $3000 \mathrm{rpm}$ for $15 \mathrm{~min}$. Each sample was labeled using codes describing the specific animal and stored at $-20^{\circ} \mathrm{C}$ until examination.

\section{3- Serological test}

The collected samples were screened for Brucella using RBPT according to the procedure recommended by (Aldomy et al. 2009). Fifty $\mu \mathrm{L}$ of RBPT antigen and $50 \mu \mathrm{L}$ of the tested serum were placed alongside on the plate, and then mixed thoroughly. The plate was shaken for $5 \mathrm{~min}$ and the degree of agglutination reaction was recorded. Agglutination indicated positive results while no agglutination considered as negative.

\section{4- Biochemical analysis}

Serum concentration of total protein, albumin, cholesterol, triglyceride, urea, creatinine, aspartate transaminase (AST) and alanine transaminase (ALT) were determined using commercially available kits (made by Randox Company in United Kingdom and Biomerieux Company in France).

\section{5- Statistical analysis}

The obtained data were analyzed statistically using student's t-test. The values present as mean \pm SE (Al-Mashadani and Hermz, 1989). 


\section{Results}

Out of 93 screened sera samples by RBPT 12 (12.9\%) were positive for Brucella spp., eight buffalos were positive (15.4 $\%)$, while four cows were positive $(9.8 \%)$ (Figure, 1).

Mean values of serum ALT, AST and total protein activities were increased significantly $(\mathrm{p}<0.05)$ in serologically positive buffalos in compare to negative ones (Table,1).The mean values of the albumin , cholesterol, triglyceride , urea and creatinine were not significantly different between seropositive and seronegative buffalos( $\mathrm{p}$-values are $0.239,0.110,0.231$, 0.222 and 0.477 respectively ) ( Table,1). The mean values of serum cholesterol, triglyceride and creatinine concentrations among seropositive cows were declined(84.50 $\pm 5.12,19.75 \pm 2.86$ and $0.95 \pm 0.12$ respectively ) (p-values are $6.295,6.363$ and 2.800 respectively) when compared to seronegative ones, while the mean value of AST was elevated significantly (68.25 $\pm 2.92 \quad) \quad(p$-value is 7.262) (Table ,2). There were not significant different between seropositive and seronegative cows considering total protein, albumin, urea and ALT (p-values are 0. 870, $1.480, \quad 0.247$ and 0.508 respectively) (Table,2).

Figure (1): Number and percentage of the infected buffalo and cow.

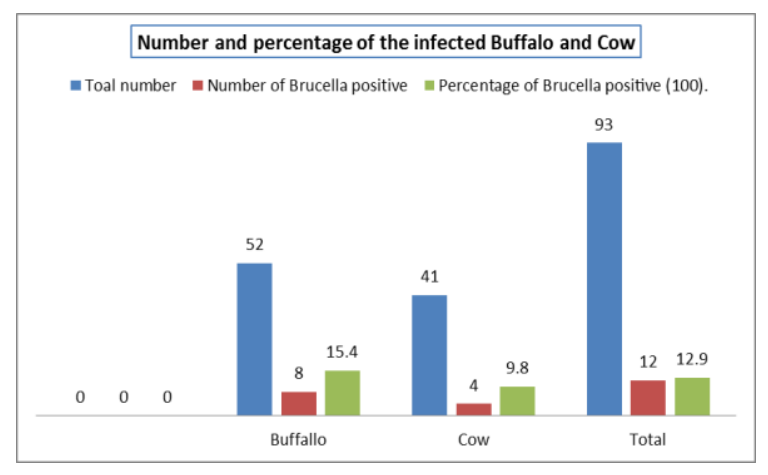

Table (1): Biochemical parameters in health and brucella infected buffalo.

\begin{tabular}{llll} 
Parameters & $\begin{array}{l}\text { Brucellosis } \\
\text { Positive }\end{array}$ & $\begin{array}{l}\text { Brucellosis } \\
\text { Negative }\end{array}$ & $\begin{array}{l}\text { p-value } \\
(0.05)\end{array}$ \\
\hline Total protein & $8.04 \pm 1.46$ & $6.61 \pm 0.69$ & 2.772 \\
Albumin & $2.51 \pm 0.38$ & $2.74 \pm 0.19$ & $0.239(\mathrm{NS})$ \\
Cholesterol & $75.50 \pm 21.23$ & $61.38 \pm 8.57$ & $0.110(\mathrm{NS})$ \\
Triglyceride & $24.13 \pm 7.77$ & $29.00 \pm 6.18$ & $0.231(\mathrm{NS})$ \\
Urea & $43.13 \pm 14.95$ & $27.25 \pm 11.45$ & $0.222(\mathrm{NS})$ \\
Creatinine & $1.56 \pm 0.85$ & $1.83 \pm 0.33$ & $0.477(\mathrm{NS})$ \\
ALT & $66.75 \pm 12.32$ & $41.38 \pm 11.23$ & 2.874 \\
AST & $208.38 \pm 67.83$ & $115.38 \pm 45.20$ & 3.672 \\
\hline \multicolumn{5}{c}{$*$ Values are expressed as mean \pm SE. } \\
\multicolumn{4}{c}{ * NS: Non-significant. }
\end{tabular}

Table (2): Biochemical parameters in health and brucella infected cow.
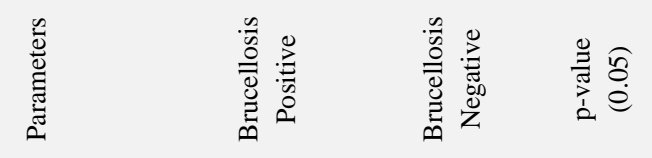

\begin{tabular}{|c|c|c|}
\hline 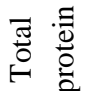 & 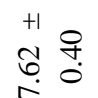 & $\stackrel{+1}{\stackrel{+}{ }} \stackrel{\infty}{=}$ \\
\hline
\end{tabular}

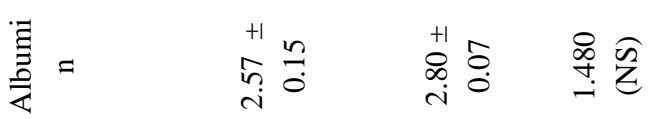

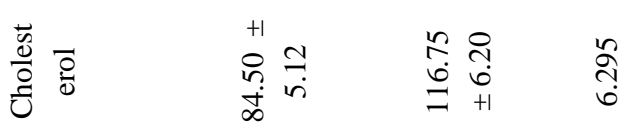

\begin{tabular}{|c|c|c|}
\hline 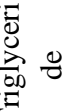 & $\begin{array}{ll}+1 & 0 \\
\stackrel{n}{2} & \infty \\
\stackrel{a}{a} & i\end{array}$ & $\begin{array}{l}+1 \\
\stackrel{1}{0} \\
\infty \\
\infty \\
\infty\end{array}$ \\
\hline
\end{tabular}

\begin{tabular}{|c|c|c|}
\hline 巴ّ & $\begin{array}{l}+1 \\
\stackrel{n}{g} \\
\stackrel{n}{g}\end{array}$ & $\begin{array}{l}8 \\
\stackrel{8}{2} \\
i\end{array}$ \\
\hline
\end{tabular}

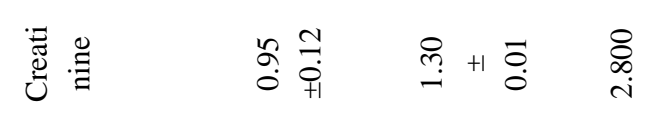

\begin{tabular}{|c|c|c|}
\hline$\stackrel{5}{4}$ & 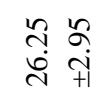 & 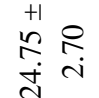 \\
\hline
\end{tabular}

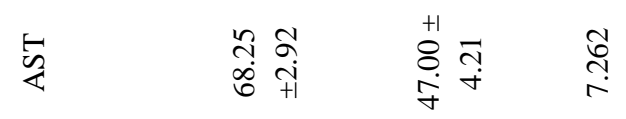

$*$ Values are expressed as mean $\pm \mathrm{SE}$.

* NS: Non-significant. 


\section{Discussion}

Brucellosis is one of the most serious animal and human diseases .It provokes placentitis, abortion, retention of the placenta and metritis and can affect the economy of a country by inflecting heavy loss to the livestock and dairy industries (Ghani etal. 1990 ; Poester etal. 2013).

In this study the results showed that the percentage rates of brucellosis using $\mathrm{RB}$ was $15.4 \%$ and $9.8 \%$ in buffalo and cows respectively, which agreed with observations reported by Arslan with his co-workers in 2011, where they found that the percentage of brucellosis in sheep using RBPT was $8.77 \%$ in Mosul city, Whereas the results recorded by Al- Naqshabendy and his coleagues in 2014 were relatively higher $(39.1 \%$ ) than observations reported in the current study although they depended on IELISA to screen for brucellosis from the different areas of Duhok city. EL Bahgy and Ali in 2017 who reported that the percentage of Brucellosis were 15 and 5\% among cows from Kafr- EL Sheikh and Qualyobia governorates respectively.

This study showed that the Brucellosis may be behind a significant elevation in serum level of AST and ALT in buffalos and AST only in cows which was agreed with results reported in new study (Nath et al., 2014; Merhan et al., 2017) who found significant elevations in serum AST and ALT of Brucella seropositive animals. The serum activities of the aminotransferase are measured to detect hepatocellular injury (Abou Eiazab, 2015) due to liver damage caused by Brucella which can explain increased release of liver enzymes into the plasma (Hoffman and Solter, 2008).
The current study revealed that the Brucellosis may be behind a significant elevation in serum total protein among tested buffalos which was similar to results recorded by Abou Eiazab in 2015 who found significant elevation in the total protein levels among cows infected with Brucella. Moreover other investigators reported significant increase in serum total protein among cattle infected with Brucellosis (Nath et al., 2014).

From the current study elevation in cholesterol, triglyceride and creatinine among tested cows were reported which was parallel to observations found by EL Bahgy and Ali in 2017. Moreover in a past study done by Nath et al., (2014), it was observed that serum cholesterol and triglyceride were significantly increased among cattle infected with Brucella. Also others recently found that total cholesterol and LDL values were increased while triglyceride, HDL and VLDL values were decreased among cattle with Brucellosis (Merhan et al., 2017). Elevation in lipid profile in cow infected with Brucella may be resulted from higher levels of free fatty acid caused by high levels of cortisol due to stress of abortion as well as increased sensitivity of infected animals to epinephrine hormone which leads to the increase in serum free fatty acid concentration (Al-Hussary and Al-Zuhairy, 2010).

The current study revealed that were no significant in albumin, cholesterol, triglyceride, urea and creatinine in seropositive buffalo, , whereas among cows significant changes were reported only for total protein, albumin and urea was agreed with observations recorded by Bouhroum and co-workers in 2012. Moreover, Hamada 
et al., ( 2013) found no significant difference in albumin and total protein between Brucella seropositive cows.

In conclusion, Brucella infection was detected to cause important changes in the biochemical parameters especially in animals. The assaying of biochemical parameters in buffalo and cows may be helpful in elucidating the etio- pathogenesis of the adverse effects associated with brucellosis.

\section{References}

1. Abou Eiazab M F.( 2015) .Evaluation of serum enzymes activities and protein fractions in Brucella infected cows .Turk.J.Vet.Anim.Sci.,39 :480-484.

2.Al- Hussary NA J and Al- Zuhairy AS.M (2010) .Effect of Toxoplasmosis and brucellosis on some biochemical parameters in ewes . Iraqi .J. Vet. Sci., 24:73-80.

3. Al-Mashadani $\mathrm{M} \mathrm{H}$ and Hermz $\mathrm{AH}$.( 1989) . Statistics . Baghdad university , 518pp.

4. Al-Naqshabendy AA, Ibrahiem AA and Azeez OH( 2014) . Effect of Brucella melitensis on the serum lipids profile in ewes . Assiut . Vet.Med. J.,60: 156- 159.

5.Altuglu I, Zeytinoglu A,Bilgic A,Kamcioglu S, Karakartal G and Smits H( 2002) . Evaluation of Brucella dipstick assay for the diagnosis of acute brucellosis. Diagn .Microbiol Infect. Dis.,44,241-243.

6. Arslan SH, Hassan MM, Mohammed HA,AL-Hussary NA and Al- Obaidi QA( 2011). Changes in some biochemical parameters accompanied with brucellosis in sheep .Iraq. J. Vet. Sci., 25:107- 110.

7. Bouhroum NL, Bensahli B and Niar A( 2012) . Evaluation of Biochemical parameters in post partum cows affected with Brucella in the Wilaya of Relizane. Afr.J.Biotechnol., 11:1818-1822.

8. Corbel $\mathrm{MJ}($ 1997). Brucellosis an overview. Emerg. Infect.Dis.,3:213-221.

9. Cutler SI, Whatmore AM and Commander $\mathrm{NJ}(2005)$. Brucellosis - new aspects of an old disease. J.Appl .Microbiol.,98:1270 1281.

10. El-Bahgy H E K and Ali A F(2017). Epidemiology and Biochemical effects of Brucellosis in Kafer - El Sheike and Qualyobia cows farms .J. Agricul. Vet. Sci. ,10: 53-59.

11.EL-Boshy M,Abbas M,EL-Khodery H and Osman S.( 2009) . Cytokine response and clinicopathological findings in Brucella infected camels ( Camelus dromedaries).Vet.Med.,54:25-32.

12. Ghani M, Siraj MZ and Naeem M.( 1995) .Sero- Epidemiological study of brucellosis among goats and sheep at Peshawar ( district ).Asian - Austral. J. Anim . Sci., 8: 489- 494.

13. Hamada D M, Mohamed AH, Mabrouk A , Emad M and Ah ME ( 2013). Seroprevalence of abortion causing agents in Egyptian sheep and goat breeds and their effects on the animals performance .J.Agric.Sci.,5:92-101.

14. Hoffman W E and Solter PE (2008). Diagnostic enzymology of domestic animals. In: Kaneko J J, Harvey J W, Bruss ML., editors. Clinical biochemistry of domestic animals. $6^{\text {th }}$ ed., San Diego, USA, Academic Press, pp.351- 378.

15.Kumar A, Srikanth N, Naresh G and Vidya B.( 2015) .Assessment and comparison of serum biochemical parameters of Brucella infected and healthy ewes . J. Livestock Sci., 6: 100- 103. 
16. Maadi H, Moharamnejad M and Haghi M ( 2011).Prevalence of brucellosis in cattle in Urmia, Iran.Pak.Vet.J.,31:81- 82.

17. Merhan O,Bozukluhan K,Kuru M, BÜYÜK F, Özden Ö and KÜKÜRT A ( 2017) .Investigation of oxidative stress index and lipid profile in cattle with brucellosis .Kafkas Univ. Vet. Fak. Derg.23:933-937.

18. Aldomy F., Alkhawaldeh M., and Younis I B. (2009). Immune responses of goats ( Shami breed )to vaccination with a full reducedand conjunctiva dose of brucella ( Brucella melitensis Rev 1) vaccine. Pak.Vet.J., 29:149-153.

19. Nath R, Das S, Sarma S and Devi M.( 2014).Comparison of blood profiles between health y and Brucella affected cattle. Vet. World, 7:668-670.

20. Pappas G, Papadimitrious P,Akritidis N, Christoul Land Tsianos EV(2006) .The new global map of human brucellosis. The Lancet Infect. Dis., 6:91-99.
21. Poester FP, Samartino LE and Santos RL (2013). Pathogenesis and pathobiology of brucellosis in livestock. Rev. Sci. Tech., 32: 105- 115.

22. Radostits OM,Gay CC, Hinchcliff K W and Constable PD (2007).A textbook of the disease in cattle, sheep ,pigs and goats.10 ${ }^{\text {th }}$ ed., Elsevier Saunders, London, UK,pp.963-974.

23. Sker M,Devecioglue C, Yaramis A, Ozbek S, Zbek $\mathrm{MN}$ and Tuzun $\mathrm{H}(2001)$.Microangiopathic , hemolytic anemia, thrombocytopenia and acute renal failure associated with acute brucellosis. Inter. Ped. , 16:105-108.

24 .Young EJ. (1995) .An overview of human brucellosis. J. Clin, Infect.Dis., 21:283-289. 